\author{
U.S. DEPARTIENT OF HEALTH, EDUCATION, AND WELFARE \\ CENTER FOR DISEASE CONTROL \\ NATIONAL INSTITUTE FOR OCCUPATIONAL. SAFETY AND HEALTH \\ CINCINNATI, OHIO 45226 \\ HEALTH HAZARD EVALUATION DETERMINATION \\ REPORT N0. 77-107-485 \\ MESTA MACHINE COMPANY \\ WEST HOMESTEAD, PENNSYLVANIA \\ APRIL, 1978
}

I. TOXICITY DETERMINATION

NIOSH conducted a Health Hazard Evaluation at Mesta Machine Company on September 27 and 28, 1977. It has been determined that a hazard to the health of workers exposed to cadmium may have existed at the Mesta Machine Company located in West Homestead, Pennsylvannia prior to the cessation of cadmium bearing babbitting operations in May, 1977.

Elevated blood and/or urine cadmium levels (indicative of possible excessive cadmium exposure) were found in 5 out of 11 potentially exposed workers tested by a Mesta contracted health 1aboratory during late May and early June, 1977. In addition, two workers who showed elevated blood and urine cadmium concentrations had symptoms compatible with chronic cadmium toxicity. In addition, these 2 workers also suffered symptoms compatible with acute cadmium inhalation poisoning during an episode in mid-April, 1977 when cadmium ingots were mistaken for non cadmium containing babitt ingots and were melted and poured into bearings without the respiratory precaution normally taken when working with cadmium.

Physical examinations and Biochemical tests conducted by NIOSH on these 2 workers and on 10 out of 11 of the other potentially exposed workers showed no abnormalities attributable to cadmium toxicity; however, the negative biochemical tests do not rule out the possibility of cadmium toxicity. The tests are insensitive indicators of cadmium toxicity and quite often are not positive until after 10-15 vears of exposure. Therefore, NIOSH can not make a definitive statement on whether the two workers have suffered adverse health effects from cadmium exposure.

I1. DISTRIBUTION AND AVAILABILITY OF DETERMINATION PEEPRT

Copies of this determination report are currently available upon request from NIOSH, Division of Technical Services, Information and Dissemination Section, 4676 Columbia Parkway, Cincinnati, Ohio 45226. After 90 days the report will be available through the National Technical Information Service (NTIS), Springfield, Virqinia 22150. Information regarding its availability through NTIS can be obtained from NINSH, Publications office at the Cincinnati address. 
Page 2 - Health Hazard Evaluation Determination Report No. 77-107

Copies of this report have been sent to:
a) Mesta Machine Company, West Homestead, Pennsylvania
b) Authorized representative of United Steel Workers of America - Local Union 7174 - 415 W. 8th Avenue, West Homestead, Pennsyivania
c) International Headquarters of United Steel Workers of America, 5 Gateway Center, Pittsburgh, Pennsylvania 15222
d) U. S. Department of Labor - Region III
e) NIOSH - Region III

For the purpose of informing the approximately 13 "affected employees", this Determination Report shall be "posted" for a period of at least 30 calendar days in a prominent place(s) readily available to the workers.

III. INTRDDUCTION

Section 20 (a) (6) of the Occupational Safety and Health Act of 1970, 29 U.S.C. 669 (a) (6), authorizes the Secretary of Health, Education, and Welfare, following a written request by any employer or authorized representative of employees, to determine whether any substance normally found in the place of employment has potentially toxic effects in such concentrations as used or found.

The National Institute for Occupational Safety and Health (NIOSH) received such a request from an authorized representative of the United Steelworkers of America - Local No. 7174 - West Homestead, Pennsylvania to evaluate potential hazards from a cadmium babbitting operation in the erecting department of Mesta Machine Company. This request was precipitated by an incident that occurred during the week of April 18, 1977. At that time the babbitters inadvertently used cadmium in a supposedly non cadmium babbitting operation and did not use the respirators, shielding and ventilation usually used with cadmium babbitting. Since that time the two principal babbitters have complained of dyspnea, nausea, fatigue, bone and joint pain.

In May and early June of 1977, blood and/or urine cadmium levels performed by a Mesta Contract Laboratory, were found to be elevated in the principal babbitters and in 3 out of 9 other potentially exposed workers. (See Table 1) In late May cadmium babbitting operations were suspended pending engineering modifications. The USWA requested that NIOSH perform a Health Hazard Evaluation to assess the potential harm to the workers health from cadmium fumes. 
Page 3 - Health Hazard Evaluation Determination Report No. 77-107

IV. HEALTH HAZARD EVALUATION

A. Process Evaluation

Mesta Machine Company manufactures equipment for steel rolling mills. The babbitting section of the erecting department performs centrifugal casting of linings of $0 i 1$ bearings and other types of bearings. The two types of babbitt metals and their alloying elements (approximate percent by weight) that are used for linings include: (1) Cadmium base containing $97.5 \%$ cadmium and $1.5 \%$ lead and (2) tin base containing $89 \%$ tin, $3.5 \%$ copper, $7.5 \%$ antimony and .25\% 1 ead. The centrifugal babbitting process involves melting the babbitt in a pot with a wooden cover while the bearing is rapidly rotated and heated. When the bearing and babbitt reach the desired temperatures the molten alloy is poured into the rotating bearing and centrifugal force distributes the metal evenly on the bearing surface. During the pouring of cadmium the babbitters wear respirators but otherwise there is no protection from the metallic oxides except a 5 horsepower, vane-axial fan positioned about 5 feet from the operation. The fan has a design capability of $1700 \mathrm{cfm}$ and is required to pull the fumes laterally and exhaust them through an approximately $50^{\prime}$ high $9^{\prime \prime}$ diameter stack directly to the outside. On September 29, during the melting of a tin base babbitt, bluish air currents were readily observed entering the building through the roof windows located near the stack exhaust by the NIOSH and Mesta representatives. It appeared that the air currents were reintroducing the metal fumes and other contaminants to the workplace.

When molten metal has been poured into the bearing, the melting pot is cleaned by placing a flame into the interior of the pot. During this process a voluminous quantity of irritating smoke is generated which spreads throughout the vicinity. It is this smoke that is most irritating to the non babbitters and the men are frequently forced to leave the area until the atmosphere clears. The fan located near the rotating bearing clears some of this smoke through the flue to the roof but much of this smoke reenters the building via open windows on the roof.

Over the last five years the frequency of cadmium babbitting has increased from two to approximately six times per month. Specific men have been assigned to this work and for the last five years, two babbitters have performed most of the babbitting. These two men most likely have had the highest exposure to metal fumes, and the approximately eleven other men (machinists, pipe fitters, and other metal workers) in the immediate area aiso may have been exposed to the iume emissions, but to lower concentrations. 
Page 4 - Health Hazard Evaluation Determination Report No. 77-107

B. Environmental and Medical Evaluation Desian and Methods

\title{
1. Environmental
}

Prior to the NIOSH field investigation of September 27 and 28 , the Mesta Machine Company ceased melting the cadmium base babbitt sometime in May. In a September 29 letter to NIOSH the company stated that none is to be scheduled for melt until engineering controls are instituted. Consequently, no environmental sampling was conducted. A follow-up survey to characterize and assess the contaminants generated from tin babbitting was not made because of the present union strike that began October 1, 1977. However, it is judged that the environmental controls that will be instituted for cadmium babbitting, most probably would also effectively control the contaminants generated from tin babbitts or any others that may be melted.

\section{Medical}

The total number of workers participating in the medical evaluation was 12 . In addition members of management provided blood and urine specimens for use as controls. The workers were all males ranging in age from 39 to 59 with an average age of 52.3. Their time of potential cadmium exposure ranged from six months to forty years with an averaqe of 20.5 years exposure. There were four babbitters with exposures of six months, three years, eight years and fifteen years respectively (the eight and fifteen year men complained of greatest symptoms). A group of eight men made up of pipefitters, sheet metal workers and machinists who worked in the vicinity of the cadmium babbitting operation but did not work directly with molten cadmium, most likely had a lower level of exposure to metalic fumes. However, these workers had a Tonger work exposure period ranging from eight to forty years (average 27.5 years).

The medical evaluation consisted of questionnaires administered to each worker, a directed physical examination, pulmonary function tests, and blood and urine analyses. The specific analyses performed were as follows :

\author{
Blood Cadmium \\ Hematocrit \\ Serum Creatinine \\ Blood Urea Nitrogen \\ Serum Multiphasic Analysis-12 (SMA-12) \\ Urine Cadmium (12 hours specimens) \\ Urine $B_{2}$ microglobul in excretion (12 hour specimens) \\ Urine protein (qualitative estimate by dip stick) \\ 12 hour creatinine clearance \\ Forced Vital Capacity (FVC) \\ Forced Expiratory Volume, 1 second (FEV 1 )
}


Page 5- Health Hazard Evaluation Determination Report No. 77-107

The questionnaire attempted to define work history, qeneral health problems and medications. Questions regarding past elevated levels of exposures to heavy metals and treatment received for such were asked. Work habits, such as eating or smoking at the plant, as well as respirator usage were also sought. Symptoms of pulmonary, renal, gastrointestinal, cardiovascular, and central nervous system disorders were asked each worker, as well as more qeneral symptoms such as fatique, weight loss, or joint complaints.

The physical examination included blood pressure measurement, brief examination of teeth and skin, auscultation of the lungs, and examination for nervous system dysfunction including sense of smell, deep tendon reflexes, wrist and ankle strength, and presence or absence of tremor.

Analys is of the blood and urine samples for cadmium were performed by the Solano Laboratories, Berkley, California. A second set of the blood and urine specimens were sent to MDS Laboratory, Cincinnnati, Ohio for hematocrit, BUN, creatinines, and urine $B_{2}$ microglobulins. $B_{2}$ microglobulins were measured using the Pharmacia R I A kit. Pulmonary function studies were performed using the "Medister" electronic machines, and predicted normal values for height, sex, and age were taken from Morris et al.

Normal values used are as follows:

1. Creatine clearance $>90 \mathrm{ml} / \mathrm{min}$.

2. BUN $(11-23 \mathrm{mg} / 100 \mathrm{ml})$

3. Serum Creatinine $(.7-1.5 \mathrm{mg} / 100 \mathrm{ml})$

4. Henoglobin - for males, $14-18 \mathrm{gm} / 100 \mathrm{ml}$ is normal.

5. Blood Cadmium - Levels in blood for non-exposed persons are less than 0.85 microgram per $100 \mathrm{ml}$.

6. Urine Cadmium - although no "normal" levels exist, a level of below $10 \mathrm{ug} / 1 \mathrm{t}$ is considered to carry no risk. ${ }^{2}$

7. Beta 2 Micro globulin - Normal values by the R I A method used are from $4-370$ uq/ 1 iter.

8. FVC/pred FVC - If less than $80 \%$ is considered an abnormal value. $(70 \%$ for men $>50)$

9. FEV $/$ /FVC - If Tess than than $70 \%$ is considered an abnormal value. 
Page 6 - Health Hazard Evaluation Determination Report No. 77-107

\section{Toxicology}

Cadmium ${ }^{2-10}$ : The toxicity of cadmium may be divided into the acute effects of high exposures and the long-term effects of chronic poisoning. In acute poisoning with airborne cadmium, the respiratory system is the only system severely injured, al though throat irritation chest pain, headache, cough, dizziness, chills, nausea, vomitina, and diarrhea all may occur. Pulmonary edema and death may occur at high levels of exposure. There is a complete absence of significant immediate symptoms that can serve to warn workers that they are receivina hazardous exposure. The effects of chronic cadmium poisoning include renal tubular dysfunction, olfactory nerve damaqe, bone chanqes, and rhinitis; alleged pulmonary emphysema, anemia, and possible increased hypertension may be included in this aroun. There is an increased incidence of renal stones in workers exposed to significant cadmium levels. Studies have indicated that carcinoma of the prostate may be found more frequently in cadmium-exposed workers, and an increased incidence of respiratory tract tumors may also be associated with increasing cadmium exposure, although this has not been definitely established. Reported symptoms of chronic cadmium toxicity include nausea, dyspnea on exertion, chronic fatique, metalic taste in the mouth, bone, muscle and joint pain.

Absorbed cadmium is retained in the body primarily in the kidney and liver. Excretion is slow. Urinary concentrations of cadmium have no diagnostic significance in terms of severity or duration of exposure and indicate only increased absorption of cadmium. With increasing exposure, however, renal excretion may increase markedly. One of the earliest changes indicating cadmium damage to the kidneys is the excretion of a low molecular weiaht protein in the urine called beta2 microglobulin. $B_{2}$ microglobul in is not of ten seen in exposed subjects unti1 after 10-15 years of exposure, although it has been seen in subjects with only four years of cadmium exposure. Elevated blood levels of cadmium indicate increased expcsure but do not correlate well with organ damage or symptoms.

\section{Results and Discussion}

Twelve out of 13 potentially exposed workers participated in the evaluation. The results of tests are seen in Table II. The creatinine clearance normally is above approximately $90 \mathrm{ml} / \mathrm{min}$ and two employees are significantly below this figure. If this decreased clearance were due to Cd renal toxicity, an elevation in the level of urinary $B_{2}$ microglobulins would be expected. An elevated $B_{2}$ microglobulins $(>370 \mathrm{ug} / 1 \mathrm{t}$ ) is the most specific finding reported with renal Cd toxicity but is frequently not present until after ten to fifteen years of $\mathrm{Cd}$ exposure. The $\mathrm{B}_{2}$ microglobulins were normal in all the subjects studied. The $C B C$ and platelets results were unremarkable. 
Page 7 - Health Hazard Evaluation Determination Report No. 77-107

$\mathrm{SMN}_{12}$ results showed various abnormalities in selected patients but no pattern of significant abnormalities as a group. The qualitative urine protein by dipstick was negative in all subjects.

The pulmonary function tests were unremarkable with exception of Subject 13, who showed (a) FEV, $69 \%$ of expected and VC (Vital Capacity) $64 \%$ of expected. (For men greater than 50 years of age, FVC \& FEV 1 should be greater than $70 \%$ of expected). This subjects normal $\mathrm{FEV}_{7} / \mathrm{VC}$ ratio (78\%) indicated restrictive lung disease as the cause of his impaired FEV 7 and vc. Chronic cadmium exposure is reported in many series to cause emphysema (an obstructive lung disease) whereas acute Cadmium Toxicity causes restrïctive lung disease. Marked obesity can also cause a restrictive picture on Puimonary Function Testing and the subject in question has a very heavy set body habitus.

Four out of twelve employees showed impaired sense of smell on physical examinations. Three out of four of these workers had a long term low level of potential exposure to cadmium fumes. Anosmia has been reported as a symptom of Cd toxicity but impared sense of smell is not uncommon in the adult population. The physical examinations of the remaining subjects revealed no significant abnormalities as a group except for moderate hypertension in 5 out of 12 men.

The blood and urine cadmium results obtained in this hazard evaluation (Table 2) are unsatisfactory. The majority of the blood Cd samples leaked in transit and the remainder showed equally elevated levels (normal less than $0.85 \mathrm{ug} / \mathrm{lt}$ ) in the two controls and four potentially exposed subjects. The urine cadmium results likewise showed equally elevated levels (normal less than $10 \mathrm{ug} / 1 \mathrm{t}$ ) in the potentially exposed and in the four control subjects. It is judged that the laboratory analysis of cadmium is not reliable and no conclusion from the values can be drawn.

The exposed workers completed a questionnaire regarding symptoms and diseases related to Cd toxicity. The two workers with the history of potentially highest cadmium exposure complained of approximately six months history of malaise, fatigue, dyspnea, metallic taste in mouth and they also complained of nausea after cadmium use. These symptoms are frequently found in patients sufferina from Cd toxicity. These subjects stated that their symptoms were exacerbated after the afore mentioned episode in late April when cadmium ingots were inadvertently melted in the babbitting operation without the usual precautions. Several other workers also complained of periods of dyspnea and cough for variable periods after this occurance and their symptoms are compatible with acute cadmium toxicity.

A summary of the questionnaire results is given in Table 3 . The incidence of respiratory symptoms (most notably shortness of breath) is compatible with the long smoking histories of the majority of the 
Page 8 - Health Hazard Evaluation Determination Report No. 77-107

workers. Of course these symptoms may have been exacerbated by cadmium exposure. The increased incidence of hypertension (5 out of 12) is noteworthy in light of the controversial reported correlation of cadmium exposure with hypertension, but the small number of workers in this study prevent a determination of significance. No conclusion can be drawn from the incidences of muscle cramps and the central nervous system symptoms of headache insomnia etc.

The two workers with a history of hiqhest Cd exposure and greatest symptomatology underwent extensive medical evaluation after their cadmium exposure ceased, without finding any objective signs that were highly correlated with Cd toxicity. However, the physical and laboratory abnormalities associated with Cd toxicity; elevated $\mathrm{B}_{2}$ microglobulins, elevated blood and urine Cd levels, impaired pulmonary function tests, and mild anemia are not always found in cadmium toxic patients especially in those subjects with less than 8 to 10 years exposure.

\section{RECOMMENDATIONS}

The following recomendations are offered to ensure worker safety and heal th:

1. Routine pre-employment medical examinations should be performed as well as periodic physical examinations. A sugrested timetable is every two years for workers below 40 years of age, then on a vearly basis thereafter.

2. The examination should consist of a medical history, physical examination, and appropriate biomedical testina. Suggested tests include:

a. Blood pressure measurement

b. Pulmonary function studies

c. Complete biood count

d. Urinalysis

e. Serum multiphasic analysis - 12 (SMA - 12)

f. Urine for cadmium (24 hour collection)

g. Urine for beta-2 microqlobulin

h. Examination of prostate glands in all male workers greater than 40 years of age.

i. Individual worker's ability to effectively use the positive or negative pressure respiratory protective equipment provided.

$j$. Urine protein determinations capable of detecting low molecular weight proteins should be done at least twice a year on all exposed workers. 
Page 9 - Health Hazard Evaluation Determination Report No. 77-107

3. Workers with evidence of high cadmium exposure should be followed closely for health effects. The following guidelines are suggested:

a. Workers with cadmium excretion of from 15 ug/gram creatinine to $35 \mathrm{ug} / \mathrm{gram}$ creatinine should have these levels repeated within four to eight months, as well as urinary beta-2 microglobulin excretion measured concurrently if the worker has had greater than five years of plant exposure.

b. Workers excreting more than 35 ug Cd/gram creatinine should be transferred to areas of lower cadmium exposure. Repeat measurements of cadmium excretion and beta-2 microglobulin excretion should be performed within four to six months.

c. All workers with elevated excretion of beta-2 microglobulin should be removed from areas of significant cadmium exposure, a complete physical examination performed, and repeat excretion measurements performed to assess the extent of renal damage or reversibility present.

4. Primary emphasis should be placed upon modifications of the cadmium exposure ${ }_{3}$ itself. Work practices, as outlined in the NIOSH Cadmium Criteria Document ${ }^{3}$, should be studied and enforced and engineering modifications employed at appropriate areas of concern. Additional ventilation systems or modifications of existing systems, as well as review of the respirator program and enforcement of existina requirements of usage, may be necessary. Worker education regarding the risks of cadmium exposure and proper hygienic practices should be stressed. Administrative manipulation of exposure to higher or lower areas of exposure should be relied upon only after other means have proven inadequate.

5. The respirator program should be monitored and enforced, including proper fitting as well as instructing the workers on things that prevent a good respirator fit such as beards, moustaches, and any stubble on the face. A respirator program must meet OSHA requirements stated in Code of Federal Regulations 1910.134.

6. Smoking and eating should be prohibited in all work areas. Cigarettes should not be allowed on the worksite.

AUTHORSHIP AND ACKNOWLEDGEMENTS

Report prepared by:

Thomas Wilcox, M.D.

Medical officer

Medical Section

Hazard Evaluation \& Technical

Assistance Branch

Cincinnati, Ohio

John R. Kominsky, M.S.

Project Officer

Industrial Hygiene Section

Hazard Evaluation \& Technical

Assistance Branch

Cincinnati, Ohio 
Page 10 - Health Hazard Evaluation Determination Report No. 77-107

Originating office:

Report Typed By:
Jerome P. Flesch, M.S. Acting Chief, Hazard Evaluations \& Technical Assistance Branch Cincinnati, Ohio

Patricia Dove Clerk Typist Medical Section Hazard Evaluation \& Technical Assistance Branch Cincinnati, Ohio

Labor and Management: NIOSH is thankful to the management and employees of Mesta Machine Company for their cooperation and assistance in conducting the Heaith Hazard Evaluation.

\section{REFERENCES:}

1. J. F. Morris et a1, Spirometric Standards for Non-Smoking Adults; American Review of Respiratory Diseases, Vo1. 103, 171.

2. Lauwerys, Robert, et al.: "Epidemiological Survey of Workers Exposed to Cadmium", Arch. Environ. Health, Vol. 28, March 1974, pp. 145-148.

3. NIOSH Criteria for a Recommended Standard...Occupational Exposure to Cadmium. HEW Publication No. (NIOSH) 76-192, 1976.

4. Ulander, Arne, et al.: "Measurement of Blood-Cadmium Levels; Lancet Apri1 13, 1974, pp. 682-683.

5. Buell, George: "Some Biochemical Aspects of Cadmium Toxicology" Journal of Occupational Medicine, Vol. 17, No. 3, March 1975.

6. Hardy, Harriet, et al.: "The Possibility of Chronic Cadmium Poisoning" Journal of Industrial Hygiene and Toxicology, Vol. 29, No. 5, P. $321,324$.

7. Bonnel1, J.A., et al.: "A Follow-up Study of Men Exposed to Cadmium 0xide Fume" Brit. J. Industrial Med. 1959, 16, 135.

8. Zenz, C Occupational Medicine, Yearbook Publishers, 1975.

9. Patty, F.A. ed. Industrial Hygiene and Toxicology, 2nd Revised Ed. Interscience Publishers. New York, 1963.

10. Prince, Frank: A Study of Industrial Exposures to Cadmium. Journal of Industrial Hygiene and Toxicology. Vol. 29, p. 320. 


\section{Table 1}

Blood and Urine Cadmium

Measurements done by Mesta Machine Co.

Mesta Machine Company

West Homestead, Pennsylvania

May-July, 1977

\begin{tabular}{|c|c|c|c|}
\hline Subject & Date & $\begin{array}{l}\text { Blood } \mathrm{Cd} u \mathrm{ug} / 100 \mathrm{cc} \\
\text { (Normal } 0.85 \mathrm{ug} / 100 \mathrm{cc} \text { ) }\end{array}$ & $\begin{array}{l}\text { Urine cd ug/100 cc } \\
\text { (Normal } 1 \mathrm{ug} / 100 \mathrm{cc} \text { ) }\end{array}$ \\
\hline A & $5 / 18 / 77$ & 2.8 * & 9.6 * \\
\hline B & $5 / 18 / 77$ & 8.2 * & 3.5 * \\
\hline c & $5 / 27 / 77$ & 0.85 & \\
\hline D & $5 / 27 / 77$ & 0.9 & \\
\hline$E$ & $5 / 27 / 77$ & 0.81 & \\
\hline$F$ & $6 / 03 / 77$ & 0.22 & 4.0 * \\
\hline G & $6 / 03 / 77$ & 0.18 & $4.3 *$ \\
\hline$H$ & $6 / 03 / 77$ & 0.11 & 0.38 \\
\hline I & $6 / 03 / 77$ & 0.56 & 0.88 \\
\hline J & $6 / 06 / 77$ & 0.15 & \\
\hline K & $6 / 06 / 77$ & 0.29 & \\
\hline$L$ & $7 / 01 / 77$ & 0.4 & \\
\hline M & $7 / 01 / 77$ & 0.33 & 1.2 * \\
\hline
\end{tabular}


Table 2

Pulmonary Function, Blood and Urine Tests Data

Mesta Machine Company

West Homestead, Pennsylvania

September 27-28, 1977

\begin{tabular}{|c|c|c|c|c|c|c|c|c|c|c|}
\hline Subjects & $\begin{array}{l}\text { WBC } \\
-\end{array}$ & $\begin{array}{l}\mathrm{Hgb} \\
-\end{array}$ & VC/YC exp. & Fev ${ }^{\stackrel{\text { Fev }}{1} \text { Exp. }_{1}}$ & $\underline{\frac{\text { Fev } 1}{\text { VC }}}$ & $\begin{array}{c}\text { Smoking } \\
\text { Pack Years }\end{array}$ & $\begin{array}{l}12 \text { hr Creat. } \\
\text { Clearance }\end{array}$ & Blood Cd & $\begin{array}{l}\text { Urine Cd } \\
\text { ug/1t }\end{array}$ & $\begin{array}{c}\text { Urine } B_{2} \\
\text { Micra globulins } \\
\text { ug/lt } \\
\end{array}$ \\
\hline $\begin{array}{l}1 \\
2 \\
3 \\
4 \\
5\end{array}$ & $\begin{array}{l}7.6 \\
8.2 \\
4.5 \\
7.3\end{array}$ & $\begin{array}{l}16.5 \\
15.7 \\
14.4 \\
15.8\end{array}$ & $\begin{array}{r}104 \% \\
86 \% \\
105 \% \\
84 \%\end{array}$ & $\begin{array}{r}105 \% \\
90 \% \\
101 \% \\
93 \%\end{array}$ & $\begin{array}{l}74 \% \\
76 \% \\
75 \% \\
81 \%\end{array}$ & $\begin{array}{l}20 \\
70 \\
12 \\
15\end{array}$ & $\begin{array}{r}116 \\
86 \\
89 \\
119\end{array}$ & $\begin{array}{l}2.5 \\
3.0 \\
1.0\end{array}$ & $\begin{array}{l}50 \\
40 \\
35 \\
30\end{array}$ & $\begin{array}{l}97 \\
30 \\
26 \\
68\end{array}$ \\
\hline $\begin{array}{r}6 \\
7 \\
8 \\
9 \\
10 \\
11 \\
12 \\
13\end{array}$ & $\begin{array}{l}4.6 \\
6.1 \\
8.7 \\
8.8 \\
7.2 \\
8.9 \\
8.0 \\
7.9\end{array}$ & $\begin{array}{l}16.1 \\
15.6 \\
15.8 \\
16.3 \\
15.0 \\
17.3 \\
16.5 \\
18.2\end{array}$ & $\begin{array}{r}104 \% \\
71 \% \\
96 \% \\
96 \% \\
103 \% \\
73 \% \\
71 \% \\
64 \%\end{array}$ & $\begin{array}{r}108 \% \\
80 \% \\
97 \% \\
92 \% \\
96 \% \\
87 \% \\
86 \% \\
69 \%\end{array}$ & $\begin{array}{l}74 \% \\
84 \% \\
75 \% \\
67 \% \\
82 \% \\
85 \% \\
91 \% \\
78 \%\end{array}$ & $\begin{array}{r}0 \\
45 \\
40 \\
40 \\
0 \\
35 \\
4 \\
0\end{array}$ & $\begin{array}{r}95 \\
61 \\
70 \\
117 \\
124 \\
118 \\
261 \\
241\end{array}$ & 2.5 & $\begin{array}{l}60 \\
45 \\
50 \\
35 \\
60 \\
55 \\
55 \\
30\end{array}$ & $\begin{array}{l}65 \\
54 \\
58 \\
44 \\
73 \\
93 \\
99 \\
54\end{array}$ \\
\hline $\begin{array}{cc}\text { Controls } & 1 \\
2 \\
3 \\
4 \\
4\end{array}$ & $\begin{array}{l}6.5 \\
8.4 \\
3.7 \\
6.7\end{array}$ & $\begin{array}{l}15.8 \\
15.8 \\
15.5 \\
18.0\end{array}$ & & & & & $\begin{array}{l}15 \\
106 \\
153\end{array}$ & $\begin{array}{l}3.0 \\
2.0\end{array}$ & $\begin{array}{l}30 \\
60 \\
30 \\
35\end{array}$ & $\begin{array}{l}32 \\
69 \\
44 \\
95\end{array}$ \\
\hline $\begin{array}{l}\text { Mean Values } \\
\text { of Exposed } \\
\text { Workers }\end{array}$ & 7.3 & 16.1 & $88 \%$ & $92 \pi$ & $78 \%$ & 31 & 125 & & 45 & 63 \\
\hline $\begin{array}{l}\text { Mean Values } \\
\text { of Controls }\end{array}$ & 6.3 & 16.2 & & & & & 132 & & 39 & 60 \\
\hline
\end{tabular}


Table 3

Symptoms Reported By Workers

Mesta Machine Company

West Homestead, Pennsylvania

September 28-29, 1977

Symptom

Number of Persons

Percent of Persons

Reporting the Symptoms Reporting the Symptoms

Pulmonary

Cough

3

Sputum

Shortness of Breath

Cadmium smoke irritation

4

7

4

25

33

58

33

Gastro intestinal

Nausea

3

25

Diarrhea

2

17

Cardiovascular

History of Hypertension

History of Myocardial Infarction

5

42

1

8

CNS

Headaches

Irritability

Sleeping Difficulties

Memory Loss

$\begin{array}{ll}2 & 17 \\ 2 & 17 \\ 3 & 25 \\ 3 & 25\end{array}$

Genera1

Fatigue

Muscle Cramps

Muscle or Bone Pain

Metalic Taste

$2 \quad 17$

542

Nasal irritation from Cadmium Fumes

$2 \quad 17$

325 